International Journal of Instruction e-ISSN: 1308-1470 • www.e-iji.net

Article submission code: 20210126115007

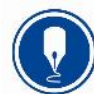

January $2022 \bullet$ Vol.15, No.1

p-ISSN: 1694-609X

pp.673-684

Received: 26/01/2021

Revision: 27/07/202
Accepted: 18/08/2021

OnlineFirst: 14/11/2021

\title{
The Effect of a Whole Brain Teaching Based Instruction on Developing Number Competencies and Arithmetic Fluency in Kindergarten Children
}

\section{Doaa Emam Ghobashy Elfiky}

Dr., Department of Educational Sciences, Faculty of Education for Early Childhood Matrouh University, Egypt, doaa_f_2020@yahoo.com

Young children need to be taught using effective interventions. A good teaching method is one that will increase children's motivation to learn, keep them aware of their understanding and encourage them to reflect on what they learn, if this teaching is based on relevant and visible training. Otherwise, they may suffer from delays in mathematics. One of these effective interventions is Whole Brain Teaching (WBT). The participants were 90 kindergarten children recruited from two public kindergarten schools in Matrouh city, Egypt. Two classes, with 45 children in KG1, were randomly selected using the fishbowl method. Children aged 4 and above (KG1 children) were targeted. In order to analyze the data from the pre- and post-test, the author used the Statistical Package for the Social Sciences (SPSS) V18.0. two- way ANOVA analysis and t-test. The findings of the study confirmed that adopting Whole Brain Teaching (WBT) approach helped in the increasing of student's involvement. Third, the intervention allowed children to see, say, hear and move physically, and this resulted in the emotional involvement in lessons presented. Gradually, as lessons progress, children become more fluent. The effectiveness of WBT had great results which were obvious on children's learning, affection and behaviour. During and after the presentation and application of the intervention, children maintained behavioural engagement. Prior to the intervention, the teacher took a long time trying to manage children.

Keywords: whole brain teaching based instruction, developing number competencies, arithmetic fluency, kindergarten children, teaching

\section{INTRODUCTION}

Kindergarten in Egypt educational system, as well as other educational systems around the world, is an important period in which teaching mathematical skills to these young children plays an important and crucial role in their subsequent achievement expectations. During this period, which is a formal stage in the educational system ladder in Egypt, children are taught different computational skills, including to solve addition and subtraction problems with objects, to sort things through the use of concrete and visible supports such as buttons and cubes to understand the calendar and

Citation: Elfiky, D. E. G. (2022). The effect of a whole brain teaching based instruction on developing number competencies and arithmetic fluency in kindergarten children. International Journal of Instruction, 15 (1), 673-684. https://doi.org/10.29333/iji.2022.15138a 
its components, such as recognizing that days are weeks, weeks are months, among other skills (Naseem, 2015).

Researchers gave children's early numerical capacities their due care and interest in the past decade (Ilona, Evelyn \& Johannes, 2018). One can assume that children's number competencies (e.g. sorting and classifying, counting objects, completing missing number (s), number comparisons, and number combinations) and Arithmetic fluency are powerful predictors of mathematics achievement and vital prerequisites to their success in mathematics. Fluency, which was originally derived from the word "flow", was given due care and attention in the fields of arithmetic in the last few decades (Vanbinst et al., 2015). It was indicated that those children who finished their kindergarten stage and entered primary school with high levels of mathematical knowledge were likely to maintain these high levels of mathematical skill for further and subsequent stages (MacDonald \& Carmichael, 2015).

Young children need to be taught using effective interventions. A good teaching method is one that will increase children's motivation to learn, keep them aware of their understanding and encourage them to reflect on what they learn, if this teaching is based on relevant and visible training (Iurea, Ioan, Safta \& Suditu, 2011). Otherwise, they may suffer from delays in mathematics. One of these effective interventions is Whole Brain Teaching (WBT) (ElAdl, 2020; ElAdl \& Eissa, 2019; Priyadarshini, Anna, Yang \& Lee, 2019). Whole Brain Teaching (WBT) can be regarded as both a multi-sensory teaching strategy as well as a brain-based learning strategy (Wolken, 2017). It is based on the principles of cooperative learning (Preslee \& Prakasha, 2017). This method helps engaging children throughout the whole learning process by activating both brain hemispheres (Biffle, 2013).

Biffle (2013), referred WBT as "Power Teaching" WBT eliminates passive learning and improves active student engagement (Priyadarshini et al., 2019)

This method as indicated by Biffle (2013) makes learning fun. When children are fully engaged and focused during lessons, it is assumed that they will get the most out of them (Hannah, 2014). The philosophy of Whole brain teaching is surrounded by seven core techniques of teaching referred to as the Big Seven (Biffle, 2013).

The WBT approach was comprised of seven teaching techniques .WBT Basics provides a simple starting point for teachers new to Whole Brain Teaching. (Clark, 2016)

Technique 1: Class-Yes: Attention Getter- The teacher, in order to get children's attention, begins class with one word by saying "class" any way the teacher likes, and the students are responsible to mimic the teachers" voice by responding "Yes" (Clark, 2016).

Technique 2: Classroom Rules: The Organizer- WBT utilized five classroom rules that were rehearsed daily. Each rule corresponded to its own gesture. The classroom rules were as follows:

Rule \#1: follow directions quickly Rule \#2: raise your hand for permission to speak Rule \#3: raise your hand for permission to leave your seat 
Rule \#4: make smart choices Rule

\section{\#5: keep your dear teacher happy}

Technique 3: Teach/Okay. Once the teacher gets the student attention, the teacher engaged in direct verbal instruction using gestures to represent the lesson concepts (Clark, 2016).

Technique 4: The Scoreboard. To support attention and motivation in the classroom the teacher created a scoreboard with a happy face on one side to represent the students and a sad face on the other side to represent the teacher (Clark, 2016).

Technique 5: Mirror. A key aspect of teaching in the WBT classroom was the use of gestures. Gestures were created to represent various concepts in the curriculum to facilitate retention of the material.

Technique 6: Hands and Eyes. When critical aspects of the lesson were presented, the teacher said, "Hands and eyes" in the usual novel tone of voice to gain student attention.

Technique 7: Switch. Students were assigned peer partners that they turned to after the "Teach!" command. The students alternated between listening to and mirroring their peers' gestures and teaching (Clark, 2016).

Many researchers and teachers (e.g. Battle, 2010; Brobeck, 2015; Calhoun, 2012; Lindstorm, 2010; Lockhart, 2016; Palasigue, 2009), when employed Whole Brain Teaching (WBT), reported positive results including significant academic gains and increases in children's engagement in the classroom.

Engagement, involvement, whole brain and principles can teach us about philosophy of whole brain teaching (Preslee \& Prakasha, 2017).

It is said, "Everyone is able to learn." It is more correct that each individual undertakes the process of learning, since man is born with a brain that learns by instinct, so learning is innate and natural in human beings. This is where the theory of brain-based learning originated. In this article, we learn about this type of learning and review some of its applications in the learning and teaching processes. (Winters, 2001).

Brain-based learning encourages teachers to think about the nature of the brain when making decisions and try to reach a larger number of learners, and that they have to realize that all students in different educational grades have different levels of brain development and have different learning styles. This approach is the best way to find and understand why one strategy works more than another. (Idi et al., 2021; Laxman and Chin, 2010; Yuli et al., 2021)

\section{Problem Statement}

Children's achievement in mathematics during their kindergarten period has been found to be the best predictor of not only later mathematics, but also their reading achievement (Claessens, Duncan, \& Engel, 2009; Claessens \& Engel, 2013). Teaching children the early number competencies will maximize their mathematics achievement (Jordan, 
Kaplan, Ramineni, \& Locuniak, 2009), otherwise, they may have mathematics learning disabilities (Mazzocco \& Thompson, 2005). As a result of their poor number competencies, and hence over relying on rote memorization, children may have weak problem-solving skills (Robinson, Menchetti, \& Torgesen, 2002). There is general consensus that learners who have mathematics difficulties in elementary school have been suffering from weaknesses in basic whole number competencies (i.e. understanding the meaning of numbers and number relationships), (Gersten, Jordan, \& Flojo, 2005).

In order for children to be successful in mathematics achievement, as well as other subjects taught in their classrooms at the kindergarten, teachers should adopt evidencedbased interventions that aim at improving their basic computational skills, including their core number competencies, among other skills (Gersten, Jordan, \& Flojo, 2005). Although Whole Brain Teaching (WBT) proved to be an evidenced-based intervention (Priyadarshini, Anna, Yang \&Lee, 2019), literature review, in our country revealed that there is a dearth of research that employs it in preschool children learning.

\section{Purpose of the study}

The purpose of this study was to investigate the effect of a whole brain teaching based instruction on developing number competencies and Arithmetic fluency among kindergarten children.

\section{Significance of the study}

As literature, in our country, about Whole Brain Teaching (WBT) reveals that there is a dearth of research that employs this method in preschool children learning, the present study contributes to the literature about Whole Brain Teaching (WBT) by gathering data from an experimental design on the effectiveness of Whole Brain Teaching (WBT) with kindergarten children. This method is flexible and can be used for all age group including kindergarten children, as it helps to increase children's involvement in learning (Biffle, 2013). Children are given the opportunity and freedom to visualize, draw and act out their learning. Helping young children to understand number concepts and relations supports them in their performances in arithmetic operations, which in turn will empower them in another mathematical domain such as geometry (National Research Council, 2009).

\section{Hypotheses}

This paper seeks to verify the following two hypotheses

H1.: There will be significant statistical differences between experimental (taught with whole brain teaching based instruction) and control (not taught with whole brain teaching based instruction) groups in number competencies Test in post-test in favor of the experimental group.

H2.: There will be significant statistical differences between experimental (taught with whole brain teaching based instruction) and control (not taught with whole brain teaching based instruction) groups in Arithmetic fluency Test in post-test in favor of the experimental group. 


\section{METHOD}

\section{Participants}

The participants were 90 kindergarten children recruited from two public kindergarten schools in Matrouh city: Adel El-Safty Primary school in Matrouh (Kindergarten) and Bahithat El Badia primary school in Matrouh (Kindergarten), Egypt. Two classes, with 45 children in KG1, were randomly selected using the fishbowl method. Children aged 4 and above (KG1 children) were targeted. Children were randomly divided into two groups: treatment and control, with equal number of children in each group. Prior to the conduct of the study, children were matched on their number competencies and Arithmetic fluency performance, which did not reach significance level.

\section{Instruments}

Number Competencies Scale. This scale was developed by the researcher for assessing number competencies (sorting and classifying, counting objects, completing missing number ( $\mathrm{s}$ ), and doing simple addition and subtraction problems) among preschool children. It has (5) subscales: sorting and classifying (4 items), counting objects (4 items), completing missing number (s) (4 items), number comparisons (4 items), and number combinations (4 items). On each of the scale items, the correct answer is given one point, while zero is given to the incorrect one. The total score for the whole scale is 20 points. The reliability of the scale in terms of internal consistency was assessed by Cronbach's $\alpha$. The items demonstrated a satisfactory level of internal consistency reliability $(\alpha=.783)$. Reliability was also calculated by using t-retest after 14 days. Correlation coefficient were .688 for the whole scale. The content validity of the scale was examined by a group of 10 experts. They assessed the relevance of each item using a four-point Likert scale (where 1 represents "irrelevant" and 4 represents "highly relevant"). They provided suggestions and comments. The items were judged to be quite or highly relevant. A content validity index was calculated at the item level (I-CVI $=.90$ ).

Arithmetic Fluency Scale. This scale was developed by the researcher for assessing Arithmetic Fluency (addition and subtraction problems) among preschool children. The scale has two paper sheets, one paper sheet for addition problems, containing 10 problems for which children give answers, and one paper sheet for subtraction problems, containing 10 problems for which children give answers on each of the scale items, the correct answer is given one point, while zero is given to the incorrect one. The total score for the whole scale is 20 points. The reliability of the scale in terms of internal consistency was assessed by Cronbach's $\alpha$. The items demonstrated a satisfactory level of internal consistency reliability $(\alpha=.812)$. Reliability was also calculated by using tretest after 14 days. Correlation coefficient was (.621) for the whole scale. The content validity of the scale was examined by a group of 10 experts. They assessed the relevance of each item using a four-point Likert scale (where 1 represents "irrelevant" and 4 represents "highly relevant"). They provided suggestions and comments. The items were judged to be quite or highly relevant. A content validity index was calculated at the item level $(\mathrm{I}-\mathrm{CVI}=.90)$. 


\section{Design}

A pretest-posttest design, where the dependent variable is measured once before the treatment is implemented and once after it is implemented, was employed.

\section{Data analysis}

Two-way ANOVA analysis and t-test were employed, run by the Statistical Package for the Social Sciences (SPSS) V18.0.

\section{Procedure}

The previously described tests were administered to children as a part of preintervention testing. Data was collected before the implementation of the whole brain teaching based instruction. Children were tested as a group in a quiet room at the children's school, during school hours, by the researcher, with the help and in the presence of their female teacher. Instruction was delivered to children by the researcher, with the help and in the presence of their female teacher. The Big Seven (Biffle, 2013) were used in each lesson. The Whole Brain Teaching (WBT) takes into account seven principles (Class-Yes: Attention Getter, Classroom Rules: The Organizer, Hands and Eyes: The Focusor, Teach- Okay: Whole brain activator, Mirror: The class unifier, Switch: The involver, and The Scoreboard: The Motivator). Children were given three training sessions weekly, each lasted for $40 \mathrm{~min}$. Instruction took place in children's regular classroom.

\section{FINDINGS}

H1.: There will be significant statistical differences between experimental (taught with whole brain teaching based instruction) and control (not taught with whole brain teaching based instruction) groups in number competencies Test in post-test in favor of the experimental group. To test this hypothesis, two-way ANOVA analysis and t- test results for the differences in post- test mean scores experimental and control groups were employed. Table1 (two-way ANOVA analysis) reported that $\mathrm{F}(1,87)=386.754$, $\mathrm{p}<.0005$. (See figure 1 for the differences in mean scores on Number Competencies).

Table 1

Tests of between-subjects effects

\begin{tabular}{lllllll}
\hline $\begin{array}{l}\text { Dependent Variable (Number Competencies): NCSPO } \\
\text { Source }\end{array}$ & $\begin{array}{l}\text { Type III Sum } \\
\text { of Squares }\end{array}$ & df & Mean Square & F & Sig. & $\begin{array}{l}\text { Partial Eta } \\
\text { Squared }\end{array}$ \\
\hline Corrected Model & $816.401 \mathrm{a}$ & 2 & 408.200 & 194.595 & .000 & .817 \\
\hline Intercept & 345.919 & 1 & 345.919 & 164.904 & .000 & .655 \\
\hline NCSP & .389 & 1 & .389 & .186 & .668 & .002 \\
\hline Group & 811.293 & 1 & 811.293 & 386.754 & .000 & .816 \\
\hline Error & 182.499 & 87 & 2.098 & & & \\
\hline Total & 16919.000 & 90 & & & & \\
\hline Corrected Total & 998.900 & 89 & & & & \\
\hline
\end{tabular}

a. R Squared $=.817$ (Adjusted R Squared $=.813$ ) 
Table 2. shows T-test results for the differences in post- test mean scores between experimental and control groups in number competencies. As shown, $\mathrm{T}=24.89, \mathrm{p}<0.01$.

Table 2

T-test results

\begin{tabular}{llllll}
\hline Group & $\mathrm{N}$ & Mean & Std. deviation & $\mathrm{T}$ & Sig. \\
\hline Experimental & 45 & 16.31 & 1.68 & 24.89 & 0.01 \\
Control & 45 & 10.28 & 1.14 & & \\
\hline
\end{tabular}

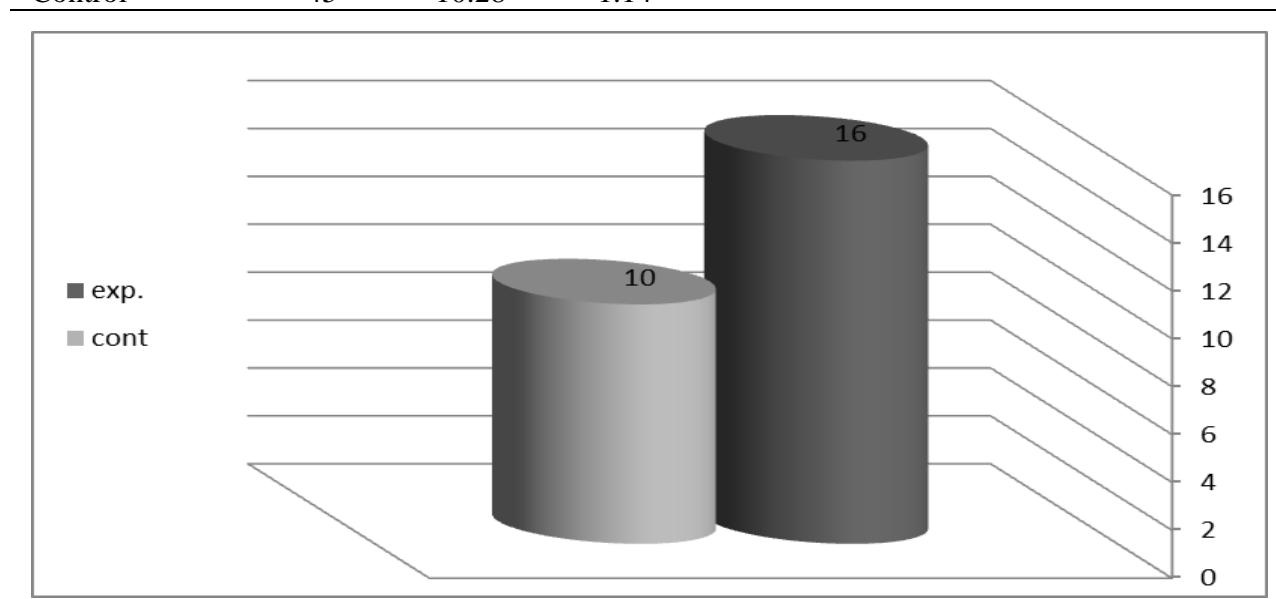

Figure 1

The difference between the two groups on number competencies

$\mathrm{H} 2 .:$ There will be significant statistical differences between experimental (taught with whole brain teaching based instruction) and control (not taught with whole brain teaching based instruction) groups in Arithmetic fluency Test in post-test in favor of the experimental group. To test this hypothesis, two-way ANOVA analysis and t- test results for the differences in post- test mean scores experimental and control groups were employed. Table3 (two-way ANOVA analysis) reported that $\mathrm{F}(1,87)=526.749, \mathrm{p}<$ .0005 . (See figure 2 for the differences in mean scores on Arithmetic fluency).

Table 3

Tests of between-subjects effects

Dependent Variable (Arithmetic Fluency): Afspo

\begin{tabular}{|c|c|c|c|c|c|c|}
\hline Source & \multicolumn{2}{|c|}{ Type III Sum } & Mean Square & $\mathrm{F}$ & Sig. & \multirow{2}{*}{$\begin{array}{l}\text { Partial } \\
\text { Squared } \\
.858\end{array}$} \\
\hline Corrected Model & $746.957 \mathrm{a}$ & 2 & 373.479 & 263.387 & .000 & \\
\hline Intercept & 432.041 & 1 & 432.041 & 304.687 & .000 & .778 \\
\hline AFSP & 1.613 & 1 & 1.613 & 1.138 & .289 & .013 \\
\hline Group & 746.923 & 1 & 746.923 & 526.749 & .000 & .858 \\
\hline Error & 123.365 & 87 & 1.418 & & & \\
\hline Total & 17653.000 & 90 & & & & \\
\hline Corrected Total & 870.322 & 89 & & & & \\
\hline
\end{tabular}

a. R Squared $=.858$ (Adjusted R Squared $=.855)$ 
Table 4 shows T-test results for the differences in post- test mean scores between experimental and control groups in Arithmetic fluency. As shown, $\mathrm{T}=24.89, \mathrm{p}<0.01$

Table 4

T-test results

\begin{tabular}{llllll}
\hline Group & $\mathrm{N}$ & Mean & Std. deviation & $\mathrm{T}$ & Sig. \\
\hline Experimental & 45 & 16.53 & 1.40 & 22.90 & 0.01 \\
Control & 45 & 10.77 & 1.01 & & \\
\hline
\end{tabular}

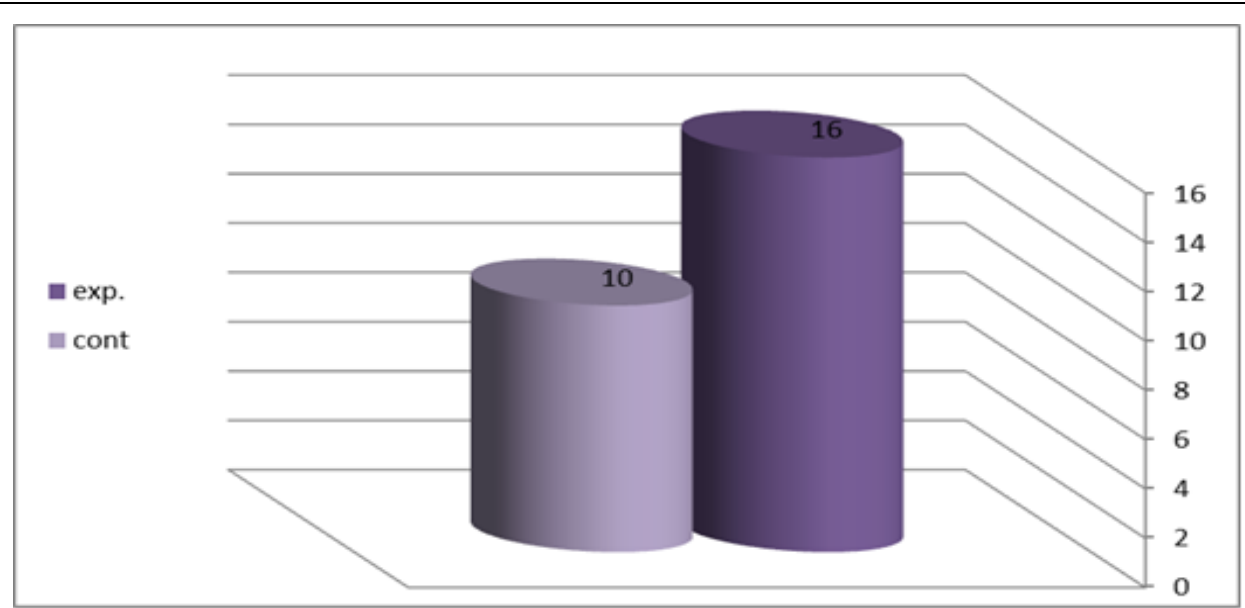

Figure 2

The difference between the two groups on arithmetic fluency

\section{DISCUSSION}

WBT which targeted number competencies and Arithmetic fluency among kindergarten children, significantly improved number competencies and Arithmetic fluency outcomes among the target children in the treatment group. Results indicate that kindergartners in the treatment group outperformed the control group only after whole brain teaching based instruction. There can be many possible explanations for these findings. First, traditional methods used in our schools do not direct students as individual toward tasks and materials, and do not challenge their abilities (Eissa, 2014, and are likely to make children feel bored and may hate the kindergarten altogether. It is well known that "The longer we talk, the more students we lose" (Biffle, 2013, P.6). when teachers adopt a technique that suits students interests and challenges their abilities with its various modalities, those students have a lot of gains (Eissa, 2012; Sutiani, Situmorang \& Silalahi, 2021).

However, when they are taught with an interesting method, one that is filled with fun, they may be engaged and motivated to learn. In this context, the results of the present study revealed significant differences in the performance of both groups; experimental (taught with whole brain teaching based instruction) and control (not taught with whole brain teaching based instruction) groups in number competencies and Arithmetic 
fluency, though they were no differences between the two groups before the treatment. This is due to using the Whole Brain Teaching (WBT) seven principles (Class-Yes: Attention Getter, Classroom Rules: The Organizer, Hands and Eyes: The Focusor, Teach- Okay: Whole brain activator, Mirror: The class unifier, Switch: The involver, and The Scoreboard: The Motivator) which proved to be interesting and prevails in fun among children.

Second, adopting Whole Brain Teaching (WBT) approach helped in the increasing of student's involvement. Third, the intervention allowed children to see, say, hear and move physically, and this resulted in the emotional involvement in lessons presented. Gradually, as lessons progress, children become more fluent.

I was especially interested in improving number competencies and Arithmetic fluency among kindergarten children as proficiency with them is likely to be a hallmark of learning and mastering mathematics when they enter primary school. Moreover, it can predict later achievement in mathematics (Jordan et al., 2009). These findings expand previous results showing that early number competencies and Arithmetic fluency can be supported effectively through targeted interventions (Clements, Sarama, Spitler, Lange, \& Wolfe, 2011; Dyson, Jordan \& Glutting, 2013; Jordan, Glutting, Dyson, HassingerDas, \& Irwin, 2012).

\section{FUTURE RESEARCH}

This study targeted number competencies and Arithmetic fluency among kindergarten children, using WBT. The value of this study lies in the targeted children (kindergarteners), as literature review, in our country revealed that there is a dearth of research that employs it in preschool children learning. Future research efforts could be devoted to children in other geographical areas and other children, e.g. at risk for learning disabilities.

\section{CONCLUSION AND SUMMARY}

Results confirmed the use of a whole brain teaching based instruction on developing number competencies and Arithmetic fluency among kindergarten children. The effectiveness of WBT had great results which were obvious on children's learning, affection and behavior. During and after the presentation and application of the intervention, children maintained behavioral engagement. Prior to the intervention, the teacher spent more time trying to manage children. Eladl \& Mourad's (2019).Additionally, it was reported that children maintained emotional engagement. They appeared happy and satisfied with the way the lessons were presented. Moreover, it was reported that children maintained cognitive engagement, and were able to solve the Math problems easier than before. Interestingly, children assimilated all the principles of the WBT, internalized each command and gave physical and verbal responses to each of them. In general, this research is in line with the goals of Egypt 2030 strategy regarding education axis, which calls for the kindergarten child to be able to learn the mathematics skills necessary for the primary school and works to develop excellence in building curricula and educational programs of the child in order to be able to contribute effectively to sustainable development and community building. 


\section{REFERENCES}

Battle, J. (2010). Whole brain teaching: Learning the way the brain is designed. Advanced'. Retrieved from http://www.advanc-ed.org/source/wholebrainteaching-learning-way-brain-designed.

Biffle, C. (2013). Whole Brain Teaching for Challenging Kids (and the rest of your class, too!)'. Yucaipa, CA: Whole Brain Teaching LLC.

Brobeck, D. (2015) Active learning pedagogies: Giving brain power a boost. Thousand Oaks, CA: California Lutheran University.

Calhoun, C. (2012). Brain based teaching: Does it really work?' Retrieved from http://files.eric.ed.gov/fulltext/ED535937.pdf (ED535937).

Claessens, A., Duncan, G., \& Engel, M. (2008). Kindergarten skills and fifth-grade achievement: Evidence from the ECLS-K'. Economics of Education Review, 28, 415427. http://dx.doi.org/10.1016/j.econedurev.

Claessens, A., \& Engel, M. (2013). How important is where you start? Early mathematics knowledge and later school successes. Teachers College Record, 115, 060306.

Clark, H.W.S. (2016). Effect of whole brain teaching on student self-concept. Walden University Scholar Works. Walden dissertations and doctoral studies. 1-43.

Clements, D., Sarama, J., Spitler, M., Lange, A., \& Wolfe, C. (2011). Mathematics learned by young children in an intervention based on learning trajectories: A largescale cluster randomized trial'. Journal for Research in Mathematics Education., 42(2), 127-166. http://dx.doi.org/10.5951/jresematheduc.42.2.0127

Dyson NI, Jordan NC, Glutting J. (2013). A number sense intervention for low-income kindergartners at risk for mathematics difficulties. Journal of Learning Disabilities, 46(2), 166-181. http://dx.doi.org/10.1177/0022219411410233

Eissa, M. (2012). The effects of advance graphic organizers strategy intervention on academic achievement, self-efficacy, and motivation to learn social studies in learning disabled second year prep students. Psycho-Educational Research Reviews 1(1), 11-21

Eissa, M. (2014). The Effect of a phonological awareness intervention program on phonological memory, phonological sensitivity, and meta phonological abilities of preschool children at-risk for reading disabilities. Psycho-Educational Research Reviews, 3(2), 71-83.

ElAdl, A. (2020). Effectiveness of a brain-based learning theory in developing mathematical skills and scientific thinking among students with learning disabilities in Oman. Psycho-Educational Research Reviews, 9(2), 67-74.

ElAdl, A.\& Eissa, M. (2019). Effect of a brain-based learning program on working memory and academic motivation among tenth grade Omani's students. PsychoEducational Research Reviews, 8(1), 42-50. 
Gersten, R., Jordan, N., \& Flojo, J. (2005). Early identification and interventions for students with mathematics difficulties". Journal of Learning Disabilities, 38(4), 293304. http://dx.doi.org/10.1177/00222194050380040301 [PubMed: 16122059].

Hannah, N. (2014). The effects of whole brain teaching strategies in the general education classroom'. A thesis submitted in partial fulfillment of the requirements for a baccalaureate degree in Childhood and Early Adolescent Education with honors in Childhood and Early Adolescent Education.

Idi, W., Ruly, M., Muhamad, U., Hamengk., \& Muslim, A. (2021). The Impact of Collaborative Learning on Learners' Critical Thinking Skills. International Journal of Instruction, 14(2), 443-460.

Ilona, F., Evelyn, H., \& Johannes, E. (2018). Counting and number line trainings in kindergarten: effects on arithmetic performance and number sense'. Front. Psychol, 9, 111. http://dx.doi.org/10.3389/fpsyg.2018.00975

Iurea, C., Ioan, N., Safta, C., \& Suditu, M. (2011). The study of the relation between the teaching methods and the learning styles - the impact upon the students' academic conduct. Procedia - Social and Behavioral Sciences, 11, 256-260 http://dx.doi.org/10.1016/j.sbspro.2011.01.072

Jordan, N., Kaplan, D., Ramineni, C., \& Locuniak, M. (2009). Early math matters: Kindergarten number competence and later mathematics outcomes'. Developmental Psychology, 45(3), 850-867.

Jordan, N., Glutting, J., Dyson, N., Hassinger-Das, B., \& Irwin, C. (2012). Building kindergartners' number sense: A randomized controlled study'. Journal of Educational Psychology, 104(3), 647-660. http://dx.doi.org/10.1037/a0029018

Khalil, M. (2003). The Socio-Economic and Cultural Status Scale'. Cairo, Dar Quba for printing, publishing and distribution.

Laxman, K.\& Chin, Y. K. (2010). Brain-based education: Its pedagogical implications and research relevance. Journal on Educational Psychology, 4(2), 1-5.

Lindstorm, N. (2010). Whole brain teaching commands students' attention: Funny gestures, chants spice up daily lessons. Daily press newspaper. California.

Lockhart, E. (2016). English as a foreign language through whole brain teaching in primary school' (Doctoral dissertation). Rovira I Virgili University.

MacDonald, A., \& Carmichael, C. (2015). A snapshot of young children's mathematical competencies: results from the Longitudinal Study of Australian Children. In: 38th Annual Conference of the Mathematics Education Research Group of Australasia (MERGA38): Mathematics Education in the Margins, 28 June-2 July 2015, Sippy Downs, Australia. 2015

Mazzocco, M., \& Thompson, R. (2005). Kindergarten predictors of math learning disability. Learning Disabilities Research \& Practice, 20(3), 142-155. 
Naseem, S. (2015). Teaching math to kindergarten children'. Amman, Dar El Masera.

National Research Council (2009). Mathematics learning in early childhood: Paths toward excellence and equity'. Washington, DC: National Academies Press.

Palasigue, J. (2009). Integrating Whole Brain Teaching Strategies to create a more engaged learning environment'. Detroit, Michigan.

Preslee, D. \& Prakasha, G. (2017). Whole Brain Teaching. IOSR Journal of Humanities and Social Science (IOSR-JHSS), 22(6),76-83.

Priyadarshini, M., Anna, P., Yang, R., \& Lee, B. (2019). Engaging Early Childhood Learners: Effectiveness of Whole Brain Teaching in Mathematics Classroom'. IOSR Journal of Humanities and Social Science (IOSR-JHSS), 24(3), 105.

Robinson, C., Menchetti, B., \& Torgesen, J. (2002). Toward a two-factor theory of one type of mathematics disabilities'. Learning Disabilities Research \& Practice, 17(2), 8189.

Sutiani, A., Situmorang, M., \& Silalahi, A. (2021). Implementation of an inquiry learning model with science literacy to improve student critical thinking skills. International Journal of Instruction, 14(2), 117-138

Vanbinst, K., Ceulemans, E., Ghesquière, P., \& De Smedt, B. (2015). Profiles of children's arithmetic fact development: a model-based clustering approach'. Journal of Experimental Child Psychology, 133, 29-46.

Winters, C. A. (2001). Brain based teaching: Fad or promising teaching method'. U.S. Department of Education. Retrieved from: http://files.eric.ed.gov/fulltext/ED455218.pdf.

Wolken, A. (2017) Brain-based learning and Whole Brain Teaching methods. Retrieved from: http://nwcommons.nwciowa.edu/education_masters/43/

Yuli I, Sumar,M., Dwiyono H.\& Komang A. (2021). The effect of problem-based learning on problem solving and scientific writing skills. International Journal of Instruction, 14(2), 11-26 